\title{
ANALISIS PENJADWALAN PROYEK PEMBANGUNAN PIER HEAD DI LOKASI JALAN TOL KRIAN - MANYAR GRESIK DENGAN METODE FUZZY LOGIC APPLICATION FOR SCHEDULING DAN PERT Studi Kasus : PT. Djamhur Multi Engineering
}

\author{
Rifki Apriyoga Prasetyo ${ }^{1)}$, Said Salim Dahda ${ }^{2)}$, Elly Ismiyah ${ }^{3)}$ \\ ${ }^{1}$ Mahasiswa Program Studi Teknik Industri Fakultas Teknik \\ Universitas Muhammadiyah Gresik \\ *Email : rifkiapriyogap27@Gmail.com
}

\begin{abstract}
ABSTRAK
Perencanaan dan penjadwalan merupakan bagian penting untuk menentukan keberhasilan suatu proyek. Masalah yang sering dihadapi dalam sebuah proyek adalah terjadinya ketidaksesuaian antara rencana awal dengan realisasi yang ada dalam pelaksanaan proyek, seberapa baik pun perencanaan awal tidak menutup kemungkinan terjadi perubahan yang mengakibatkan keterlambatan penyelesaian. Penelitian ini menggunakan metode penjadwalan dengan mengakomodasi ketidakpastian durasi menggunakan metode Fuzzy Logic Application For Scheduling (FLASH) untuk mengetahui kemungkinan terselesainya proyek. FLASH merupakan metode penjadwalan dengan tetap mengakomodasi ketidakpastian, FLASH menggunakan terminologi posibilitas dari pada probabilitas untuk mengekspresikan ketidakpastian. Hal ini menjadikan. FLASH lebih terbuka dalam hal ketidakpastian, FLASH juga menganalisis semua jalur untuk menghasilkan posibilitas suatu total durasi proyek yang diharapkan dan melakukan perbandingan hasil perhitungan dengan metode PERT. Hasil akhir dari pengembangan penelitian menggunakan metode fuzzy didapatkan waktu dari jadwal yang dihasilkan waktu pelaksanaan proyek Pier head seksi II Bunder dapat diketahui bawah proyek tersebut dapat diselesaikan dalam waktu $(51,69,89)$ hari kerja, dengan nilai defuzzyfikasi 62 hari dari 65 hari kerja yang telah ditentukan kontraktor, dari hasil analisis perbandingan antara metode Fuzzy dengan PERT didapat waktu penyelesaian yang berbeda akan tetapi selesai waktu dari kedua penyelesaian tidak terlalu jauh. Untuk metode PERT menghasilkan durasi pengerjaan selama 56 hari sedangkan metode Fuzzy pengerjaan selama 62 hari. Selisih durasi antara kedua metode yaitu 6 hari kerja.
\end{abstract}

\section{Kata Kunci : Analisis durasi kerja, Fuzzy Logic Application For Scheduling, PERT.}

\section{PENDAHULUAN}

Perencanaan dan penjadwalan merupakan bagian penting untuk menentukan keberhasilan suatu proyek. Masalah yang sering dihadapi dalam sebuah proyek adalah terjadinya ketidaksesuaian antara rencana awal dengan realisasi yang ada dalam pelaksanaan proyek, seberapa baik pun perencanaan awal tidak menutup kemungkinan terjadi perubahan yang mengakibatkan keterlambatan penyelesaian. Bahwa suatu proyek merupakan upaya yang mengerahkan sumber daya yang tersedia, yang diorganisasikan untuk mencapai tujuan, sasaran dan harapan penting tertentu serta harus diselesaikan dalam jangka waktu terbatas sesuai dengan kesepakatan. Proyek adalah aktivitas sementara dari personil, material, serta sarana untuk menjadikan /mewujudkan sasaran - sasaran (goals) proyek dalam kurun waktu tertentu yang kemudian berakhir (Dipohusodo, 1995).

PT. Waskita Karya (persero) Tbk. merupakan salah satu Badan usaha milik Negara yang terdepan dalam industri konstruksi dari perancangan, perencanaan, dan pengawasan. Dalam proyek pembangunan jalan tol ini PT. Waskita Karya (persero) Tbk. yang bekerja sama dengan sub kontraktor yaitu salah satunya adalah PT. Djamhur Multi Engineering yang menyediakan material dan bertugas untuk pembangunan Pier Head dibagian seksi II Bunder pada proyek jalan tol Krian Legundi - Bunder - Manyar (KLBM). Pada kenyataan dalam penyelesaian aktivitas suatu proyek mengalami keterlambatan dari durasi waktu yang ditentukan .tabel 1.1 adalah waktu penyelesaian proyek yang memiliki kegiatan - kegiatan yang sejenis dengan kegiatan Proyek Pier Head yang dilaksanakan oleh PT. Djamhur Multi Engineering.

Dari tabel 1 terlihat adanya keterlambatan waktu/durasi penyelesaian proyek yang bisa jadi sebenarnya proyek - proyek tersebut tidak mengalami keterlambatan, tetapi ada faktor yang menyebabkan proyek terlambat diantaranya pada saat penentuan waktu penyelesaian proyek yang dijanjikan pada pemilik

proyek dan estimasi proyek yang bersifat subjektif, sehingga terjadi penjadwalan yang tidak akurat dan mengakibatkan keterlambatan dalam penyelesaian proyek, Oleh karena itu dibutuhkan pendekatan yang tepat untuk menentukan waktu proyek. Adapun faktor yang mempengaruhi keterlambatan tersebut terdiri dari faktor non teknis dan non teknis. Faktor teknis terdiri dari adanya kesalahan pada saat pengukuran atau perubahan desain. Selain itu faktor non teknik contoh : masalah pengadaan material dan alat berat. 
Tabel 1 Waktu penyelesaian proyek

\begin{tabular}{|c|c|c|c|c|c|}
\hline $\begin{array}{l}\mathrm{N} \\
\mathrm{O}\end{array}$ & Nama Proyek & $\begin{array}{c}\text { Ukuran } \\
\text { Pier } \\
\text { Head } \\
\left(\mathrm{m}^{2}\right)\end{array}$ & $\begin{array}{c}\text { Planning } \\
\text { (Hari) }\end{array}$ & $\begin{array}{c}\text { Aktual } \\
\text { (Hari) }\end{array}$ & $\mathrm{C}$ \\
\hline 1 & $\begin{array}{l}\text { Pembangunan } \\
\text { Pier Head } \\
\text { diGempol - } \\
\text { Pasuruan Seksi } \\
2 \text {. }\end{array}$ & $\begin{array}{c}30 \times 7 \times \\
6\end{array}$ & 65 & 73 & \begin{tabular}{ll}
\multicolumn{2}{l}{ Terlambat 8 hari } \\
disebabkan: \\
$-\quad$ & kontraktor \\
& yang kurang \\
& ahli atau \\
& berpengalaman. \\
- & Keterlambatan \\
& penyediaan \\
& material. \\
- & Kerusakan \\
& peralatan.
\end{tabular} \\
\hline 2 & $\begin{array}{l}\text { Pembangunan } \\
\text { Pier Head di } \\
\text { Ngawi- } \\
\text { Kertosono } \\
\text { Seksi } 1 .\end{array}$ & $\begin{array}{c}35 \times 7 \times \\
6\end{array}$ & 68 & 75 & \begin{tabular}{ll}
\multicolumn{2}{l}{ Terlambat 7 hari } \\
disebaban: \\
$-\quad$ & Keterlambatan \\
& penyediaan \\
& material. \\
- & Ketersediaan \\
keuangan \\
selama \\
pelaksanaan. \\
$-\quad$ Perubahan \\
material pada \\
bentuk, fungsi, \\
dan spesifikasi.
\end{tabular} \\
\hline 3 & $\begin{array}{l}\text { Pembangunan } \\
\text { Pier Head di } \\
\text { Pasuruan- } \\
\text { Probolinggo } \\
\text { Seksi 1. }\end{array}$ & $\begin{array}{c}30 \times 8 \times \\
6\end{array}$ & 60 & 69 & \begin{tabular}{cc}
\multicolumn{2}{l}{ Terlambat 9 hari } \\
\multicolumn{2}{c}{ disebabkan: } \\
- & Keterlambatan \\
& penyediaan \\
& material. \\
- & Kekurangan \\
& tenaga kerja \\
- & Kerusakan \\
& peralatan.
\end{tabular} \\
\hline 4 & $\begin{array}{l}\text { Pembangunan } \\
\text { Pier Head } \\
\text { diSemarang- } \\
\text { Solo Seksi } 5 .\end{array}$ & $\begin{array}{c}35 \times 7 \times \\
6\end{array}$ & 65 & 75 & 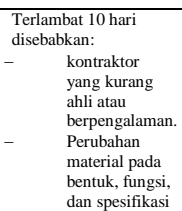 \\
\hline
\end{tabular}

Dalam manajemen proyek ada beberapa metode penjadwalan lain yang biasa digunakan seperti Gantt Chart, Precedence Diagram method (PDM), Program Evaluation Review Technique (PERT), Graphical Evaluation Review Technique (GERT) dan sebagainya. Berbeda dengan CPM, PERT memberikan alternatif lain dengan mengasumsikan durasi aktivitas bersifat tidak pasti (Wibowo, 2001) . PERT juga memiliki kekurangan diantaranya perkiraan waktu yang cenderung subjektif, terlalu fokus pada jalur kritis, kegiatan proyek harus didefinisikan dengan jelas, hubungan antar kegiatan harus ditunjukkan dan dikaitkan (AryoAndriNugroho , 2007). Untuk mengatasi masalah tersebut maka dapat digunakan sebuah metode Fuzzy Logic Application for Scheduling (FLASH). Teori Fuzzy Set yang dinamakan metode Fuzzy Logic Application for Scheduling (FLASH) untuk mengetahui kemungkinan terselesaikannya proyek. (M. Hamzah H., Saifoe EL Unas, Widiarsa)Salah satu aplikasi terpentingnya adalah untuk membantu dalam melakukan pengambilan keputusan. Konsep logika fuzzy mudah dimengerti, sangat fleksibel, dan memiliki toleransi terhadap data - data yang tidak tepat (Sri Kusumadewi, 2004), Metode ini menggunakan terminology posibilitas dari pada probabilitas untuk mengekspresikan ketidakpastian dalam menganalisis waktu penyelesaian proyek dengan durasi aktivitas dinyatakan dalam Triangular Fuzzy Number (TFN) (Wibowo, A, 2001).
Dari latar belakang yang telah diuraikan diatas peneliti akan menerapkan metode metode Fuzzy Logic Application for Scheduling (FLASH) untuk mendekati ketidakpastian waktu aktivitas proyek dan untuk menyusun jadwal pada proyek pembangunan Pier Head diseksi II (Bunder).

\subsection{Perumusan Masalah}

Berdasarkan latar belakang diatas dapat diidentifikasi masalah yaitu bagaimana analisis penjadwalan proyek pembangunan Pier Head di lokasi seksi II (Bunder) jalan tol Krian - Manyar Gresik dengan menggunakan Fuzzy Logic Application for Scheduling (FLASH)?

\subsection{Tujuan Penelitian}

Dari permasalahan yang dikemukakan di atas, tujuan yang ingin dicapaipeneliti adalah sebagai berikut:

1. Menentukan bentuk jaringan proyek pembangunan Pier Head di lokasi seksi II dengan metode Fuzzy Logic Application for Scheduling (FLASH)?

2. Menentukan mana saja pekerjaan yang termasuk pekerjaan kritis menggunakan metode Fuzzy Logic Application for Scheduling (FLASH) ?

3. Menentukan target/rencana penjadwalan proyek pembangunan Pier Head dengan metode Fuzzy Logic Application for Scheduling (FLASH) ?

\subsection{Manfaat Penelitian}

Adapun manfaat yang nantinya diharapkan dari pelaksanaan penelitian ini adalah sebagai berikut:

1. Mengetahui alur jaringan pelaksanaan proyek pembangunan Pier Head di lokasi seksi II.

2. Mengetahui pekerjaan/ aktivitas yang membutuhkan perhatian khusus.

3. Mengetahui estimasi durasi pekerjaan.

\subsection{Batasan Masalah}

Adapun batasan masalah dalam pembahasan laporan ini adalah:

1. Tidak membahas masalah teknis dalam pelaksanaan.

2. Tidak memperhatikan perhitungan biaya masing-masing aktivitas.

3. Penelitian ini dilakukan di proyek Pier Head seksi II Bunder.

\subsection{Asumsi-Asumsi}

Asumsi - asumsi yang digunakan dalam permasalahan atau dalam pelaksanaan proyek ini adalah sebagai berikut :

1. Ketersediaan sumber daya pada proyek dianggap tidak ada gangguan.

2. Skill pekerja yang digunakan sesuai dengan dengan standard dan mempunyai banyak pengalaman.

3. Tidak ada penambahan sumber daya selama penelitian. 


\section{Metodologi penelitian}

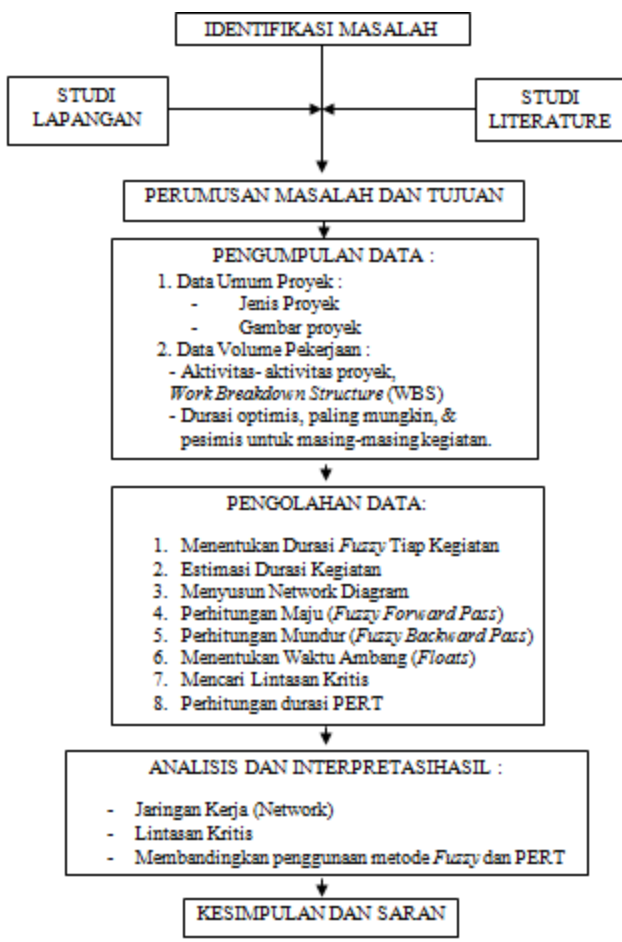

Gambar 1. Flow Chart Kerangka Penelitian

\section{Pengumpulan Data dan pengolahan data}

Pada bab ini berisi data - data yang telah dikumpulkan dalam penelitian. data - data tersebut diperoleh dari hasil pengamatan maupun wawancara dengan pihak - pihak yang terkait diperusahaan dalam menjalankan proyek - proyek yang sejenis sebagai bahan acuan untuk perencanaan penjadwalan proyek pembangunan Pier head jalan tol Data tersebut meliputi data primer yang diperoleh langsung melalui observasi serta data wawancara dengan narasumber sebagai berikut;

- Nama : Arif Rahman Hakim

- Bagian : Logistic

\subsection{Gambaran Singkat Perusahaan}

PT Wakista Karya adalah Badan Usaha Milik Negara (BUMN) yang bergerak pada bidang konstruksi, didirikan pada tanggal 1 Januari 1961 beralamatkan di Jakarta, Indonesia bergerak dalam bidang Property, Hotel, Jalan tol, Precast, Energi dan konstruksi.

\subsection{Data Umum Proyek}

- Nama proyek : Proyek jalan tol Krian Legundi - Bunder - Manyar (KLBM)

- Lokasi proyek : Seksi II Bunder.

- Sub kontraktor :PT. Djamhur Multi Engineering.
Adapun pekerjaan yang harus dilaksanakan kontraktor dalam rangka perjanjian meliputi kegiatan - kegiatan sebagai berikut :

- Penyediaan material dan tenaga kerja.

- Penyediaan peralatan / perlengkapan yang diperlukan untuk pelaksanaan sampai dengan penyerahan hasil pekerjaan dan perawatan serta pemeliharaan hasil pekerjaan.

\subsection{Data Hubungan Antar Pekerjaan}

Hubungan keterkaitan pekerjaan diperoleh dari logika ketergantungan yang disebabkan oleh sifat kegiatan itu sendiri, dengan memperhatikan kegiatan apa yang dimulai terlebih dahulu (Predecessor). Kegiatan apa yang mengikuti (Successor) dan adakah kegiatan yang bisa dilakukan secara bersamaan / sejajar untuk menghemat waktu. Disamping itu juga hubungan antar pekerjaan memiliki ketergantungan yang disebabkan oleh sifat kegiatan itu sendiri dikarenakan pekerjaan tersebut tidak dapat dimulai tanpa adanya input berupa hasil pengerjaan pekerjaan sebelumnya.

Tabel 2 Hubungan Antar Pekerjaan Proyek

\begin{tabular}{|c|c|c|c|c|c|}
\hline \multirow{2}{*}{\multicolumn{2}{|c|}{ Altivitas }} & \multicolumn{3}{|c|}{ Waltu flazy } & \multirow{2}{*}{$\begin{array}{l}\text { Kegiatan } \\
\text { pendahulu }\end{array}$} \\
\hline & & $\mathrm{a}$ & $\mathrm{b}$ & $\mathrm{c}$ & \\
\hline $\bar{A}$ & Pelkerjaen pendahuluan & 3 & 4 & 5 & \\
\hline B & $\begin{array}{l}\text { Pekrejaan tiang pancang } \\
\text { Pier head }\end{array}$ & 2 & 3 & 4 & A \\
\hline $\mathrm{C}$ & $\begin{array}{l}\text { Pelkerjan Bektisting } \\
\text { stopper }\end{array}$ & 11 & 13 & 16 & B \\
\hline D1 & Pelkejasen cor beton & 4 & 5 & 6 & $\mathrm{C}$ \\
\hline$\overline{\mathrm{D} 2}$ & $\begin{array}{l}\text { Pelkejaen pembersihan } \\
\text { stopper }\end{array}$ & 2 & 3 & 4 & $\mathrm{C}$ \\
\hline $\bar{E}$ & $\begin{array}{l}\text { Pelkejasen pasang list } \\
\text { pembersihan dan instalasi }\end{array}$ & 3 & 5 & 6 & $\mathrm{D} 2$ \\
\hline $\bar{F}$ & $\begin{array}{l}\text { Pelkerjaen } \\
\text { BekistingColwnn }\end{array}$ & 2 & 3 & 4 & E \\
\hline G & Pelkejaen cor Colwonn & 3 & 4 & 6 & $\bar{F}$ \\
\hline H & $\begin{array}{l}\text { Pekerjaen finishing Pier } \\
\text { Cap den Colwnn }\end{array}$ & 3 & 5 & 6 & G \\
\hline I & $\begin{array}{l}\text { Pelerjasn Bektisting pier } \\
\text { head }\end{array}$ & 2 & 3 & 5 & $\mathrm{H}$ \\
\hline J1 & Pelkerjan cor beton & 2 & 3 & 4 & I \\
\hline $\mathrm{J} 2$ & $\begin{array}{l}\text { Pelkejjaen pasang list } \\
\text { Anghur }\end{array}$ & 4 & 5 & 7 & I \\
\hline $\mathbf{K}$ & Pekejaen Bigralls & 5 & 7 & 8 & $\sqrt{2} 2$ \\
\hline $\bar{L}$ & $\begin{array}{l}\text { Pekerjaen finishing Pier } \\
\text { head den Bigwall }\end{array}$ & 5 & 6 & 8 & $\bar{K}$ \\
\hline
\end{tabular}

Jaringan Kerja (Diagram Network)

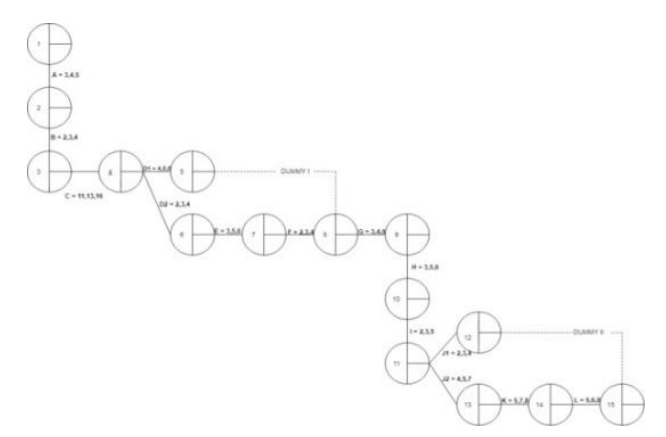


Gambar 2 jaringan kerja

\section{Tinjaun Pustaka}

Kriteria kesuksesan suatu pengelolaan proyek adalah apabila sasaran proyek dapat terpenuhi, (Kerzner, 1984) penyelesaian proyek tidak melebihi waktu yang ditentukan, tidak melebihi biaya yang ditentukan, mencapai kinerja dan teknologi yang diinginkan, serta menggunakan sumber daya yang telah ditentukan secara efektif dan efisien. Sejalan dengan perkembangan zaman, sasaran suatu proyek menjadi lebih luas, yaitu dengan menambahkan factor kualitas, keamana dan lingkungan sebagai sasaran utama yang harus dicapai dalam pengelolahan suatu proyek.

\subsection{Pengertian Manajemen Proyek}

Proyek adalah kegiatan sementara yang dilakukan untuk menciptakan suatu produk atau jasa. Menurut Imam Soeharto, proyek adalah gabungan dari berbagai sumber daya berupa manusia, material dan alat untuk melaksanakan serangkaian kegiatan yang dihimpun dalam suatu wadah organisasi sementara guna mewujudkan gagasan yang timbul karena naluri manusia untuk berkembang dengan batasan biaya, waktu dan mutu yang telah ditentukan. (Imam Soeharto, 1997) Kegiatan proyek dapat diartikan sebagai suatu kegiatan sementara yang berlangsung dalam waktu yang terbatas, dengan alokasi sumber daya tertentu dan dimaksudkan untuk melaksanakan tugas yang sasaran telah digariskan dengan jelas.

Dari pengertian diatas terlihat bahwa ciri pokok proyek adalah:

1. Memiliki tujuan yang khusus dan produk akhir atau hasil kerja akhir.

2. Jumlah biaya, sasaran, jadwal serta kriteria mutu dalam proses mencapai tujuan telah ditentukan.

3. Bersifat sementara, dalam arti umumnya dibatasi oleh waktu selesainya tugas. Titik awal dan akhir ditentukan dengan jelas.

4. Non-ruti, tidak berulang-ulang, jenis dan intensitas kegitan berubah sepanjang proyek berlangsung.

\subsection{Metode Penjadwalan Proyek}

Pemilihan metode penjadwalan pada suatu proyek dapat dipengaruhi oleh jenis pekerjaannya apakah merupakan pekerjaan berulang atau tidak, besar atau kecilnya proyek, ataupun sifat/karakteristik dari proyek yang lain. Metode dalam penjadwalan dan pengendalian proyek saat ini mengalami perkembangan, dalam usaha meningkatkan kualitas perencanaan dan pengendalian proyek telah diperkenlakan berbagai teknik dan metode.

\subsection{Work Breakdown Structure (WBS)}

Pemecahan pekerjaan besar menjadi elemenelemen pekerjaan yang lebih kecil sering disebut Work Breakdown Structure (WBS). Pemecahan ini akan memudahkan pembuatan jadwal proyek dan estimasi ongkos serta menentukan siapa yang harus bertanggung jawab. Sampai sejauh mana pekerjaan harus dipecah tidak ada pedoman yang baku. Sejauh pekerjaan itu sudah cukup mudah dilaksanakan, dapat ditentukan waktu penyelesaiannya, bisa diukur kemajuannya, sumber daya apa yang diperlukan dan biaya yang diperlukan bisa dihitung, itu berarti sudah cukup memadai tingkat pemecahan proyek ini bisa mengikuti tingkatan seperti tabel 2 .

Tabel 3 Tingkatan dalam WBS

Sumber (Santoso, 2009)

\begin{tabular}{|l|l|}
\hline Tingkat & Deskripsi \\
\hline 1 & Proyek \\
\hline 2 & Tugas \\
\hline 3 & Sub-Tugas \\
\hline 4 & Paket Pekerjaen \\
\hline
\end{tabular}

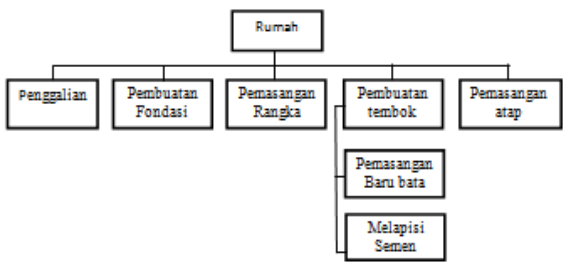

Gambar 3 WBS untuk membangun rumah Sumber (Santoso, 2009)

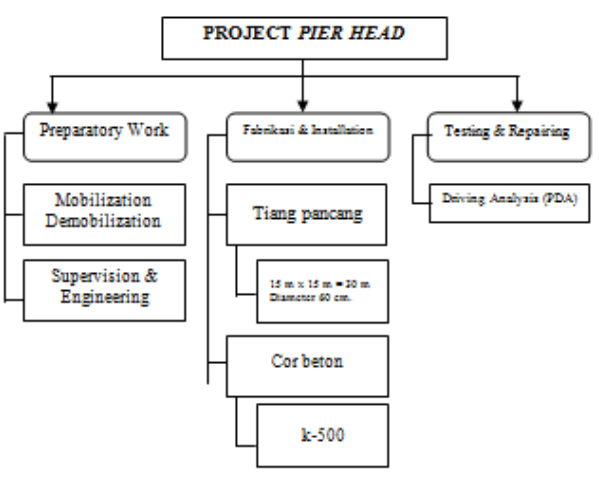

Gambar 4 :Work Breakdown Structure (WBS) Project Pier head.

\section{Metode FLASH}

FLASH pada dasarnya sama dengan CPM dalam hal activity on arrow (AOA) diagram dan perhitungannya kecuali karakteristik durasinya. Durasi aktivitas $\mathrm{i}-\mathrm{j}$ dinyatakan dalam tiga nilai berbeda : batas bawah, paling mungkin dan batas atas. Karena FLASH mengasumsikan durasi aktivitas dinyatakan dalam bilangan fuzzy segitiga, ketiga nilai tersebut merupakan nilai $1, \mathrm{~m}$, dan $\mathrm{u}$ atau Di-j $(1, \mathrm{~m}, \mathrm{u})$. untuk node i, Early Start (Ei), dan Latest Start (Li) merupakan bilangan fuzzy juga tetapi tidak harus selalu bilangan fuzzy segitiga. 


\subsection{Durasi Fuzzy Kegiatan}

Durasi kegiatan dinyatakan dalam TFN (Triangular Fuzzy Number)

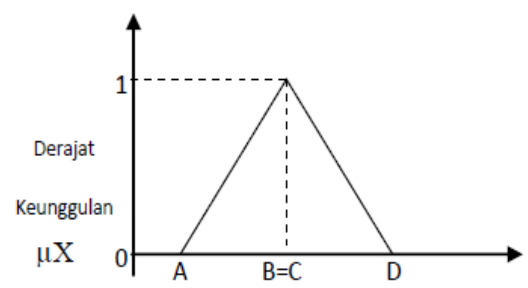

Gambar 5 Waktu Fuzzy dalam bentuk TFN

Nilai A dikenal sebagai durasi terpendek yang mungkin (most optimistic time) . D adalah durasi paling lama (most pessimistic time) dan durasi yang paling mungkin (most likely time). Dalam kaitanya dengan manajemen proyek, bilangan Fuzzy akan dioperasikan antara lain menurut operasioperasi sebagai berikut:

Misalnya 2 buah TFN M(a,b,c,d) dan N(e,f,g,h)

$\mathrm{M}(+) \mathrm{N}=(\mathrm{a}+\mathrm{e}, \mathrm{b}+\mathrm{f}, \mathrm{c}+\mathrm{g}, \mathrm{d}+\mathrm{h})$

$\mathrm{M}(-) \mathrm{N}=(\mathrm{a}-\mathrm{h}, \mathrm{b}-\mathrm{g}, \mathrm{c}-\mathrm{f}, \mathrm{d}-\mathrm{e})$

$\operatorname{Min}(\mathrm{M}, \mathrm{N})=[\Lambda(\mathrm{a}, \mathrm{e}), \Lambda(\mathrm{b}, \mathrm{f}), \Lambda(\mathrm{e}, \mathrm{g}), \Lambda(\mathrm{d}, \mathrm{h})]$

$\operatorname{Max}(\mathrm{M}, \mathrm{N})=[\mathrm{V}(\mathrm{a}, \mathrm{e}), \mathrm{V}(\mathrm{b}, \mathrm{f}), \mathrm{V}(\mathrm{c}, \mathrm{g}),(\mathrm{d}, \mathrm{h})]$

Dimana $(+)=$ operasi penjumlahan fuzzy

$(-)=$ operasi pengurangan fuzzy

$\Lambda$ =maksimum

$\mathrm{V}=$ minimum

Operasi maksimum dan minimum merupakan perbandingan pada tiap titik dalam dua TFN, dan keluarannya merupakan bilangan bilangan yang sesuai dengan operatornya (maksimum/minimum). Jadi misalkan A $(1,5,5,6)$ dan B $(3,4,4,7)$, maka max A dan B menghasilkan $(3,5,5,7)$ (Dikutip dari Aries, A. 2015. "perencanaan jadwal proyek pembangunan dermaga VI dengan metode PERT dan fuzzy PERT".Gresik:SKRIPSI)

\subsection{Parameter Waktu Kegiatan Fuzzy}

Untuk mencari jalur kritis, sebelumnya harus dicari parameter - parameter waktu dari tiap kegiatan. Parameter waktu tersebut adalah :

a. FES (Fuzzy Early Start)

Waktu mulai paling awal suatu kegiatan dapat dilaksanakan.

b. FEF (Fuzzy Early Finish)

kegiatan.

Waktu selesai paling awal dari suatu

c. FLS (Fuzzy Late Start)

Waktu paling akhir suatu kegiatan boleh dimulai, yaitu waktu paling akhir kegiatan boleh dimulai tanpa memperlambat proyek secara keseluruhan.

d. FLF (Fuzzy Late Finish)

Waktu paling akhir kegiatan boleh selesai tanpa memperlambat penyelesaian proyek.

\subsection{Fuzzy Forward Pass (Perhitungan maju)}

Perhitungan maju adalah perhitungan yang dimulai dari node start (awal) dan bergerak ke end (akhir) untuk menghitung Fuzzy early start (FES) dan Fuzzy Early Finish (FEF).

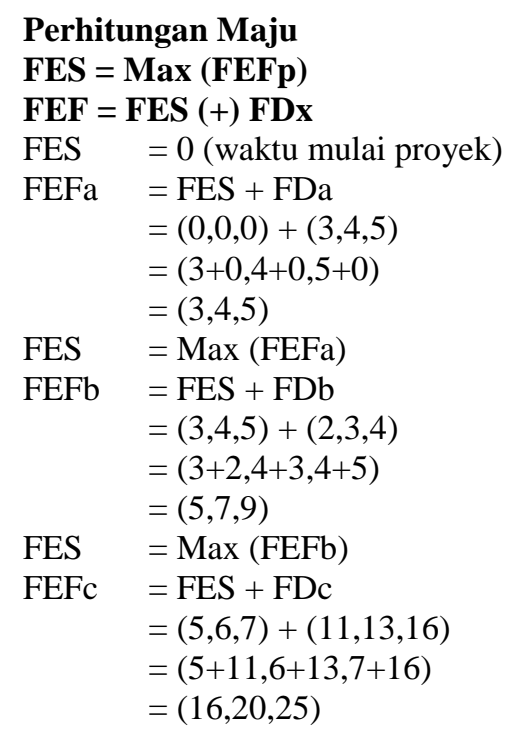

Tabel 4 Hasil Perhitungan Fuzzy Forward Pass (Perhitungan Maju)

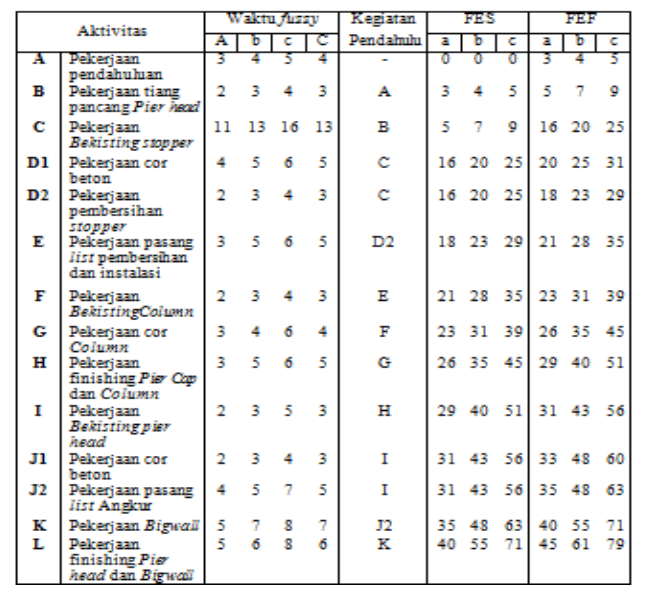

Keterangan

a - Nilai terkecil

$\mathrm{b}$ - Nilai yang paling mungkin,

FES - Fuzzy Early Start

FEF - Fuzzy Early Finish

c - Nilai terbesar C - Centroid

5.4 Fuzzy Backward Pass (Perhitungan Mundur)

Proses backward pass dilakukan untuk mencari FLS dan FLF, diawali dengan kegiatan terakhir sampai dengan kegiatan awal, backward pass dilakukan dengan perhitungan sebagai berikut :

1. FLS dari kegiatan terakhir dalam proyek adalah sama dengan FES-nya (kegiatan terakhir dalam proyek adalah simpul finish yang FD-nya adalah $(0,0,0,0))$ 
2. Kemudian dihitung PLFx $=\min ($ FLSs $=$ waktu mulai terlama dari kegiatan sebelumnya (arah dari akhir proyek ke awal).

3. PLF kemudian dikonversi menjadi FLFu (Batas atas dari waktu selesai terlama) dengan rumus :

$$
\mathrm{Au}=(\mathrm{a}, \mathrm{b}, \mathrm{c}, \mathrm{d})(-)(0,0, \infty, \infty)=(-\infty,-\infty, \mathrm{c}, \mathrm{d})
$$

4. dengan FEF (a,b,c,d) dan FLFu $((-\infty,-\infty, \mathrm{e}, \mathrm{f})$ dari suatu kegiatan diketahui maka akan dicari FLF dengan langkah - langkah sebagai berikut :

a. Mencari dari kedua angka tersebut mana yang mempunyai kemiringan kekanan lebih besar, dengan cara membandingkan (f-e) dengan (d-c).

b. Menghitung Y, yaitu sebuah besaran fuzzy terbesar yang memenuhi syarat FEF (+) Y <FLFu

c. Jika kemiringan kekanan dari FEF lebih besar $(\mathrm{d}-\mathrm{c})>(\mathrm{f}-\mathrm{e})$ atau bisa dikatakan lebih tidak pasti maka bagian kanan dari FLF dibuat sama dengan FEF. Dan Y didapat dari : $\mathrm{Y}=(\mathrm{f}-\mathrm{d}, \mathrm{f}-\mathrm{d}, \mathrm{f}-\mathrm{d}, \mathrm{f}-\mathrm{d})$

d. Jika kemiringan ke kanan dari FLFu yang lebih besar maka bagian kanan FLF disamakan dengan FLFu namun bagian kiri disamakan dengan bagian kiri dari FEF. Maka $\mathrm{Y}$ adalah : $\mathrm{Y}=(\mathrm{e}-\mathrm{c}, \mathrm{e}-\mathrm{c}, \mathrm{e}-\mathrm{c}, \mathrm{f}-$ d)

5. Kemudian FLF dapat dihitung dengan rumus :

$$
\text { FLF }=\text { FEF }(+) \mathrm{Y}
$$

6. dan FLS kemudian didapat dari penurunan rumus :

FLS (+) FD = F

Perhitungan mundur dilakukan untuk mencari menghitung Fuzzy Late Start(FLS) dan Fuzzy Late Finish (FEF). Perhitungan dimulai dari kegiatan paling terakhir sampai dengan kegiatan awal.

$$
\begin{aligned}
\text { FLF } & =\text { Min }(\text { FLSp) } \\
\text { FLSx } & =\text { FLF }- \text { FDx } \\
\text { FLP1 } & =\text { Min (FLSl) } \\
\text { FLS1 } & =\text { FLF }- \text { FDl } \\
& =(45,61,79)-(5,6,8) \\
& =(45-8,61-6,79-5) \\
& =(37,55,74) \\
\text { FLPk } & =\text { Min (FLSl) } \\
\text { FLSk } & =\text { FLF }- \text { FDk } \\
& =(40,55,71)-(5,7,8) \\
& =(40-8,55-7,71-5) \\
\text { FLPj2 } & =(29,48,69) \\
\text { FLSj2 } & =\text { FLF }- \text { FDj2 } \\
& =(35,48,63)-(4,5,7) \\
& =(35-7,48-5,63-4) \\
& =(22,43,65)
\end{aligned}
$$

\begin{tabular}{|c|c|c|c|c|c|c|c|c|c|c|c|c|}
\hline \multirow{2}{*}{\multicolumn{2}{|c|}{ Altivitas }} & \multicolumn{4}{|c|}{ Waktu fusay } & \multirow{2}{*}{$\begin{array}{l}\text { Kegiatan } \\
\text { pendahum }\end{array}$} & \multicolumn{3}{|c|}{ FLS } & \multicolumn{3}{|c|}{ FLF } \\
\hline & & a & & & & & \begin{tabular}{l|l}
$a$ & \\
\end{tabular} & & $c$ & \begin{tabular}{l|l}
$\mathrm{a}$ \\
\end{tabular} & \begin{tabular}{|l|l}
$\mathrm{b}$ & $\mathrm{g}$ \\
\end{tabular} & \\
\hline$A$ & \begin{tabular}{|l|} 
Pekerjaan \\
pendahuluan
\end{tabular} & 3 & 4 & 5 & & - & 0 & 0 & 34 & 0 & & \\
\hline B & $\begin{array}{l}\text { Pelerjaan tiang } \\
\text { pancang Pier } \\
\text { head }\end{array}$ & 2 & 3 & 4 & 3 & A & 0 & 4 & 37 & 0 & $7 \quad 3$ & \\
\hline c & $\begin{array}{l}\text { Pekerjan } \\
\text { Bekisting stopper }\end{array}$ & 11 & 13 & 16 & 13 & B & 0 & 7 & 39 & 0 & 205 & \\
\hline D1 & $\begin{array}{l}\text { Pekerjaan cor } \\
\text { beton }\end{array}$ & 4 & 5 & 6 & 5 & c & & 15 & 46 & 0 & 205 & \\
\hline D2 & $\begin{array}{l}\text { Pekerjaan } \\
\text { pembersihan } \\
\text { stopper }\end{array}$ & 2 & 3 & 4 & 3 & c & 0 & 20 & 50 & 0 & 235 & \\
\hline E & $\begin{array}{l}\text { Pekerjaan pasang } \\
\text { list pentershina } \\
\text { dan instalasi }\end{array}$ & 3 & 5 & 6 & 5 & D2 & 0 & 23 & 52 & 1 & 285 & \\
\hline F & $\begin{array}{l}\text { Pekerjan } \\
\text { BekistingCoilumn }\end{array}$ & 2 & 3 & 4 & 3 & E & 1 & 28 & 55 & 5 & 315 & \\
\hline G & $\begin{array}{l}\text { Pelkefjaan cor } \\
\text { Column }\end{array}$ & 3 & 4 & 6 & 4 & F & 5 & 31 & 57 & 11 & 356 & \\
\hline H & $\begin{array}{l}\text { Pekerjaan } \\
\text { finishing Pio } \\
\text { Cap dan Coilumn }\end{array}$ & 3 & 5 & 6 & 5 & G & 11 & 35 & 60 & 17 & 406 & 63 \\
\hline I & $\begin{array}{l}\text { Peikerjaan } \\
\text { Bexisting iigr } \\
\text { head }\end{array}$ & 2 & 3 & 5 & 3 & H & 17 & 40 & 63 & 22 & 436 & \\
\hline ग1 & $\begin{array}{l}\text { Pekerjaan cor } \\
\text { beton }\end{array}$ & 2 & 3 & 4 & 3 & I & 18 & 40 & 63 & 22 & 436 & \\
\hline $\mathrm{J} 2$ & $\begin{array}{l}\text { Pekerjan pasang } \\
\text { list Anguru }\end{array}$ & 4 & 5 & $?$ & 5 & I & 22 & 43 & 65 & 29 & 486 & \\
\hline $\mathrm{K}$ & Pekerjan Bigwail & 5 & $?$ & 8 & $?$ & $J_{2}$ & 29 & 48 & 69 & 37 & 557 & \\
\hline L & $\begin{array}{l}\text { Pekefiaan } \\
\text { finishing Pir } \\
\text { head dan Bigurall }\end{array}$ & 5 & 6 & 8 & 6 & $\mathrm{~K}$ & 37 & 55 & 74 & 45 & 617 & 79 \\
\hline
\end{tabular}

Tabel 5 Hasil Perhitungan Fuzzy Forward Pass (Perhitungan Maju)

Keterangan

a - Nilai terkecil

$\mathrm{b}$ - Nilai yang paling mungkin

FLS-Fuzzy Late Start

FLF - Fuzzy Late Finish

c - Nilai terbesar

C-Centroid

5.5 Perhitungan Slack (Waktu Ambang)

Ada tiga waktu ambang yaitu waktu ambang Total Float (TF), waktu ambang bebas atau Free Float (FF), dan waktu ambang Independent (IF). Pada metode Fuzzy, Slack dapat dihitung dengan rumus :

- $\mathrm{TFx}=$ FLFx - FDx - FESx

- $\mathrm{FFx}=\mathrm{FEFx}-\mathrm{FDx}-\mathrm{FESx}$

- IF $=$ FEFx - FDx - FLSX

Dimana notasi $\mathrm{x}$ menujukkan suatu kegiatan , dan C = Nila Centroid. Sedangkan nilai centroiddari sebuah TFN (a,b,c) dapat dihitung dengan rumus ( Dikutip dari Miftakhul, A H. 2014. Perencanaan Penjadwalan Proyek Kantor PT. Gresik Jasatama Dengan Metode Fuzzy Logic Application For Scheduling (FLASH). Gresik: SKRIPSI) :

$$
(C)=\frac{\mathrm{a}+\mathrm{b}+\mathrm{c}}{3}
$$

$$
\begin{aligned}
& \text { TFx = FLFx }- \text { FDx }- \text { FESx } \\
& \mathrm{TFa}=\mathrm{FLFa}-\mathrm{FDa}-\mathrm{FESa} \\
& =(0,4,37)-(3,4,5)-(0,0,0) \\
& =(0-5-0),(4-4-0),(37-3-0) \\
& =(0,0,34) \\
& \text { nilai centroidnya }(C)=\frac{0+0+34}{3}=11
\end{aligned}
$$


$\mathrm{TFb}$

$$
\begin{aligned}
& =\mathrm{FLFb}-\mathrm{FDb}-\mathrm{FESb} \\
& =(0,7,39)-(2,3,4)-(3,4,5) \\
& =(0-4-5),(7-3-4),(39-2-3) \\
& =(0,0,34)
\end{aligned}
$$

nilai centroidnya $(C)=\frac{0+0+34}{3}=11$

$$
\begin{aligned}
\text { FFx } & =\text { FEFx }- \text { FDx }- \text { FSx } \\
\text { FFa } & =\text { FEFa }- \text { FDa }- \text { FESa } \\
& =(3,4,5)-(3,4,5)-(0,0,0) \\
& =(3-5-0),(4-4-0),(5-3-0) \\
& =(0,0,2)
\end{aligned}
$$

nilai centroidnya $(C)=\frac{0+0+2}{3}=1$

$\mathrm{FFb}$

\begin{tabular}{|c|c|c|c|c|c|c|c|c|c|c|c|c|c|}
\hline \multirow{2}{*}{\multicolumn{2}{|c|}{ Alsivians }} & \multicolumn{4}{|c|}{$T$} & \multicolumn{4}{|c|}{$\overline{F F}$} & \multicolumn{4}{|c|}{17} \\
\hline & & 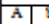 & & & $c$ & \begin{tabular}{l|l}
3 & \\
&
\end{tabular} & b & c & $\mathrm{c}$ & a & b & $\mathrm{c}$ & \\
\hline A & Pekerjas peadolshom & ל & & 14 & $\pi$ & ب & 0 & 2 & $T$ & 0 & 0 & 2 & \\
\hline B & 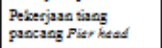 & 0 & 0 & 34 & 11 & 0 & 0 & 4 & 1 & 0 & 0 & 7 & \\
\hline c & 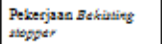 & & 0 & 34 & 14 & & 0 & 9 & 3 & 0 & 0 & 9 & 3 \\
\hline D1 & Peikerjasa cor betson & 0 & 0 & 80 & 10 & 0 & 0 & 11 & 4 & 0 & 18 & 27 & 15 \\
\hline D2 & 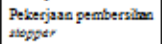 & 0 & 0 & 24 & 11 & & 0 & 26 & 9 & 0 & 0 & 27 & 9 \\
\hline $\mathbf{F}$ & 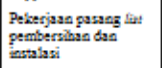 & 0 & 0 & 34 & 11 & & 0 & 14 & 5 & 0 & 0 & 32 & 11 \\
\hline $\mathbf{F}$ & 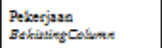 & & 0 & 4 & 11 & & 0 & 16 & 5 & 0 & 0 & 37 & 12 \\
\hline G & & 0 & 0 & 34 & 11 & 0 & 0 & 19 & 6 & 0 & 0 & 37 & 12 \\
\hline н & 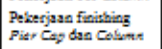 & 0 & & 34 & 11 & 0 & 0 & 22 & 7 & 0 & 0 & 37 & 12 \\
\hline I & $\begin{array}{l}\text { Petergasn Btkinitg } \\
\text { Dist kesad }\end{array}$ & 0 & 0 & 24 & 11 & & 0 & 25 & 8 & 0 & 0 & 37 & 12 \\
\hline $\mathrm{J} 1$ & & 0 & 0 & 32 & 11 & 0 & 0 & 2 & 1 & 0 & 6 & 40 & 15 \\
\hline $\mathrm{J}_{2}$ & $\begin{array}{l}\text { Pekerjaso pasang fot } \\
\text { Anghox }\end{array}$ & 0 & & 34 & 11 & 0 & 0 & 25 & 8 & 0 & 0 & 34 & 11 \\
\hline $\mathrm{k}$ & & 0 & & 34 & 11 & 0 & 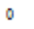 & 31 & 11 & 0 & & 37 & 12 \\
\hline L & $\begin{array}{l}\text { Pekerjysu foinithing } \\
\text { Pist ksad dan Bignelf }\end{array}$ & 0 & 0 & 34 & 11 & 0 & 0 & 34 & 12 & 0 & 0 & 37 & 12 \\
\hline
\end{tabular}

$$
\begin{aligned}
& =\mathrm{FEFb}-\mathrm{FDb}-\mathrm{FESb} \\
& =(5,7,9)-(2,3,4)-(3,4,5) \\
& =(5-4-5),(7-3-4),(9-2-3) \\
& =(0,0,4)
\end{aligned}
$$

nilai centroidnya $(C)=\frac{0+0+4}{3}=1$

$$
\begin{aligned}
\text { IFx } & =\text { FEFx }- \text { FDx }- \text { FLSx } \\
\mathrm{IFa} & =\text { FEFa }- \text { FDa }- \text { FLSa } \\
& =(3,4,5)-(3,4,5)-(0,0,33) \\
& =(3-5-33),(4-4-0),(5-3-0) \\
& =(0,0,2)
\end{aligned}
$$

nilai centroidnya $(C)=\frac{0+0+2}{3}=1$

$\mathrm{IFb}$

$$
\begin{aligned}
& =\mathrm{FEFb}-\mathrm{FDb}-\mathrm{FLSb} \\
& =(5,7,9)-(2,3,4)-(0,4,37) \\
& =(5-4-37),(7-4-4),(9-2-0) \\
& =(0,0,7)
\end{aligned}
$$

nilai centroidnya $(C)=\frac{0+0+7}{3}=2$

Tabel 6 Hasil Perhitungan Slack atau waktu ambang

\begin{tabular}{|c|c|c|}
\hline so & LINTASA & SLACK \\
\hline 1. & $A-B-C-D 2-B \cdot R-G-H-1-12-R-L$ & $1-2-2-3-9-411-12-12-12-12-12-11-112-12$ \\
\hline 2. & $A-B-C-D]-B-P-G \cdot H \cdot I-J]-R-L$ & $1-2-3-3-15-11-12-12-12-12-12-12-15-12-12$ \\
\hline 2. & $A-B-C \cdot D 2-B-B-G-H-1 \cdot \pi 1-R-L$ & $1-2-3-9-9-11-12-12-12-12-12-15-12-12$ \\
\hline${ }^{*}$ & $A-B-C-D]-B-B-G-H-I-\sqrt{2}-\mathrm{K}-\mathrm{L}$ & 1-2-2-3-15-11-12-12-12-12-11-12-12 \\
\hline
\end{tabular}

Keterangan

a - Nilai terkecil

$\mathrm{b}-$ Nilai yang paling mungkin

$\mathrm{TF}$ - Total Float

FF - Free Float

IF-Independent Float

$\mathrm{c}$ - Nilai terbesar

C-Centroid

5.6 Lintasan Kritis metode FLASH.
Lintasan Kritis adalah merupakan lintasan pada aktivitas kegiatan yang tidak boleh terjadi keterlambatan, apabila terjadi keterlambatan maka umur proyek akan bertambah sebesar keterlambatan tersebut. Dari pengolahan diatas didapat alur lintasan kerja yang berwarna merah sebagai berikut.

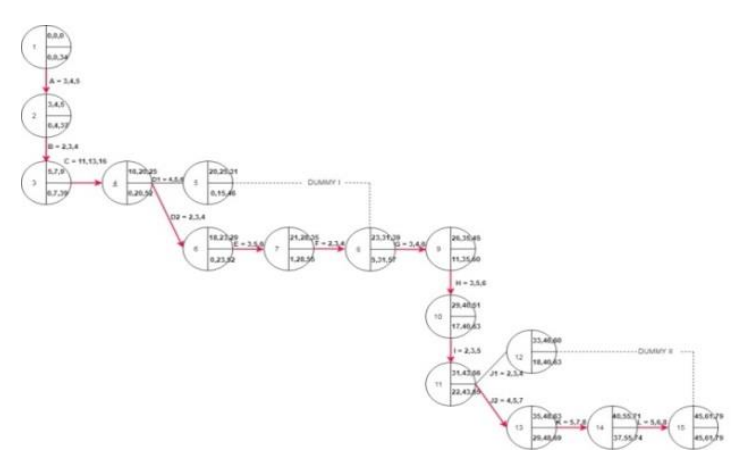

Gambar 6 Lintasan Jaringan kerja

Dari alur kegiatan pada jaringan kerja diperoleh lintasan kerja sebagai berikut :

Tabel 7 Lintasan Kritis Kerja Proyek

Dengan Waktu penyelesaian $=\frac{45+61+79}{3}=62$ hari.

\section{Metode PERT}

PERT atau Project Evaluation and Review Technique adalah sebuah model Management Science untuk perencanaan dan pengendalian sebuah proyek(Siswanto, 2007).Metode ini pertama kali digunakan dalam proyek sistem rudal Polaris di Angkatan Laut Amerika Serikat. Proyek ini penuh ketidakpastian dalam hal waktu kegiatan. PERT adalah salah satu metode yang menggunakan jaringan kerja (network), di samping CPM (Critical Path Method).

Ciri utama PERT adalah adanya tiga perkiraan waktu: waktu pesimis (b), waktu paling mungkin (m), dan waktu optimis (a). ketiga waktu perkiraan itu selanjutnya digunakan untuk menghitung waktu yang diharapkan (expected time).

Waktu optimis, a, adalah waktu minimum dari suatu kegiatan, di mana segala sesuatu akan berjalan baik, sangat kecil kemungkinan kegiatan selesai sebelum waktu ini.

Waktu paling mungkin, $\mathrm{m}$, adalah waktu normal untuk menyelesaikan kegiatan. Waktu ini 
paling sering terjadi seandainya kegiatannya bisa diulang.

Sedangkan waktu pesimis, b, adalah waktu maksimal yang diperlukan suatu kegiatan, situasi ini terjadi bila nasib buruk terjadi. Estimasi waktu-waktu tersebut diperoleh dari orang yang ahli atau orang yang akan melakukan kegiatan tersebut. Ketiga waktu estimasi tersebut berhubungan dengan bentuk distribusi beta dengan parameter a dan $b$ pada titik akhir dan $\mathrm{m}$ sebagai modus, data yang paling sering terjadi.

\subsection{Kelebihan dan kekurangan metode PERT}

1. Kelebihan pada metode PERT

a. Berguna pada tingkat manajemen proyek.

b. Secara matematis tidak terlalu rumit.

c. Menampilkan secara grafis menggunakan jaringan untuk menunjukkan hubungan antar kegiatan.

d. Dapat ditunjukkan jalur kritis, jalur yang tidak ada slack nya atau halangan.

e. Dapat memantau kemajuan proyek.

f. Dapat diketahui waktu seluruh proyek akan diselesaikan.

g. Mengetahui apa saja kegiatan kritis yaitu kegiatan yang akan menunda proyek jika terlambat dikerjakan.

h. Apa kegiatan non-kritis : kegiatan yang boleh dikerjakan terlambat.

i. Mengetahui probalilitas proyek selesai pada waktu tertentu.

j. Mengetahui jumlah uang yang dibelanjakan sesuai rencana sesuai dengan proyek tersebut.

k. Efisiensi jumlah sumber daya yang ada dapat menyelesaikan proyek tepat waktu.

2. Kekurangan pada metode PERT

a. Kegiatan proyek harus didefinisikan dengan jelas.

b. Hubungan antar kegiatan harus ditunjukkan dan dikaitkan.

c. Perkiraan waktu cenderung subjektif oleh perancang PERT.

d. Terlalu focus pada jalur kritis, jalur yang terlama dan tanpa hambatan (AryoandriNugroho, 2007).

Jaringan kerja metode PERT dapat dilakukan dengan cara nilai ES dari kegiatan kegiatan sesudahnya serta waktu LF dari kegiatan kegiatan sebelumnya untuk metode PERT. Sama seperti analisis dalam metode Fuzzy, bila jaringan kerja telah memenuhi syarat maka jaringan kerja akan dianalisis jalur kritis akan dapat diketahui.

\subsection{Metodologi PERT}

PERT merupakan metode yang digunakan dalam analisis network. Analisis network bertujuan untuk membantu dalam penjadwalan dan pengawasan kompleks yang saling berhubungan dan saling tergantung satu sama lain. Hal ini dilakukan agar perencanaan dan pengawasan semua kegiatan itu dapat dilakukan secara sistematis, sehingga dapat diperoleh efisiensi kerja. Metodologi PERT divisualisasikan dengan suatu grafik atau bagan yang melambangkan ilustrasi dari sebuah proyek. Diagram jaringan ini terdiri dari beberapa titik (nodes) yang merepresentasikan kejadian (event) (Aryo Ardi Nugroho, 2007).

a. Kegiatan pada titik (activity on node - AON)

Pada AON, titik menunjukkan kegiatan.

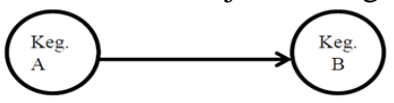

Gambar 7 Hubungan peristiwa dan kegiatan pada AON (AryoAndriNugroho, 2007)

b. Kegiatan pada panah (activity on arrow - AOA) Pada AOA, panah menunjukkan aktivitas.

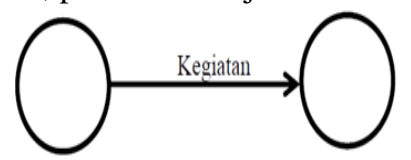

Gambar 8 Hubungan peristiwa dan kegiatan pada AOA (AryoAndriNugroho, 2007)

AOA kadang-kadang memerlukan tambahan kegiatan dummy untuk memperjelas hubungan. Kegiatan dummy adalah kegiatan yang sebenarnya tidak nyata, sehingga tidak membutuhkan waktu dan sumber daya. Dummy digambarkan dengan garis putus-putus dan diperlukan bila terdapat lebih dari satu kegiatan yang mulai dan selesai pada event yang sama. Kegunaan dari kegiatan dummy (semu) yaitu:

a. Untuk menunjukkan urutan pekerjaan yang lebih tepat bila suatu kegiatan tidak secara langsung tergantung pada suatu kegiatan lain.

b. Untuk menghindari network dimulai dan diakhiri oleh lebih dari satu peristiwa dan menghindari dua kejadian dihubungkan oleh lebih dari satu kegiatan.

Contoh :

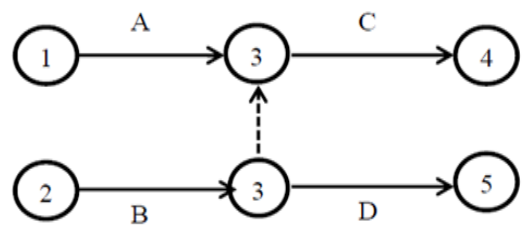

Gambar 89 Contoh Kegiatan Dummy (AryoAndriNugroho, 2007)

Keterangan:

Kegiatan A dan B harus sudah selesai sebelum kegiatan C dapat dimulai. Sedangkan D dapat dimulai segera setelah B selesai dan tidak bergantung dengan A.

\subsection{Komponen-komponen dalam pembuatan} PERT

Komponen-komponen dalam pembuatan PERT adalah :

a. Kegiatan (activity) 
Suatu pekerjaan/tugas dimana penyelesaiannya memerlukan periode waktu, biaya, serta fasilitas tertentu. Kegiatan ini diberi simbol tanda panah.

\section{b. Peristiwa (event)}

Menandai permulaan dan akhir suatu kegiatan. Peristiwa diberi symbol lingkaran (nodes) dan nomor, dimana nomor dimulai dari nomor kecil bagi peristiwa yang mendahuluinya.

Hal yang perlu diperhatikan dalam pembuatan network PERT:

1. Sebelum suatu kegiatan dimulai, semua kegiatan yang mendahului harus sudah selesai dikerjakan.

2. Anak panah menunjukkan urutan dalam mengerjakan pekerjaan.

3. Nodes diberi nomor supaya tidak terjadi penomoran nodes yang sama.

4. Dua buah peristiwa hanya bisa dihubungkan oleh satu kegiatan (anak panah).

5. Network hanya dimulai dari suatu kejadian awal yang sebelumnya tidak ada pekerjaan yang mendahului dan network diakhiri oleh satu kejadian saja (AryoAndriNugroho, 2007).

Berikut adalah penjelasan network PERT melalui contoh gambar.

1. Sebuah kegiatan (activity) merupakan proses penyeleaian suatu pekerjaan selama waktu tertentu dan selalu diawali oleh node awal dan diakhiri oleh node akhir yaitu saat tertentu atau event yang menandai awal dan akhir suatu kegiatan.

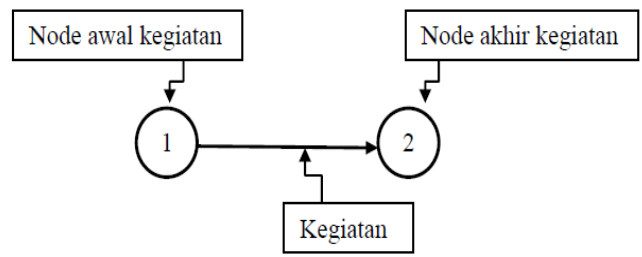

Gambar 10 Awal kegiatan 1ke 2

(AryoAndriNugroho, 2007)

2. Kegiatan B baru bisa dimulai dikerjakan setelah kegiatan A selesai

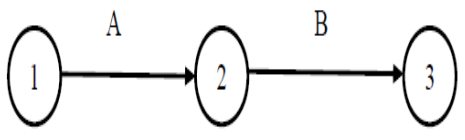

Gambar 11 Kegiatan B dikerjakan setelah kegiatan A (AryoAndriNugroho, 2007)

3. Kegiatan $\mathrm{C}$ baru bisa mulai dikerjakan setelah kegiatan A dan B selesai.

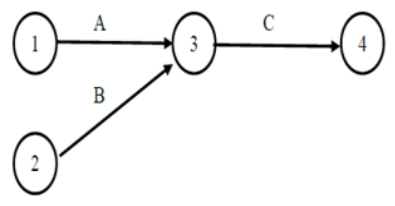

Gambar 12 Kegiatan C dikerjakan setelah kegiatan A dan B (AryoAndriNugroho, 2007)

\subsection{Komponen-komponen dalam pembuatan PERT adalah}

a) Kegiatan (activity)

Suatu pekerjaan/tugas dimana penyelesaiannya memerlukan periode waktu, biaya, serta fasilitas tertentu. Kegiatan ini diberi simbol tanda panah.

b) Peristiwa (event)

Menandai permulaan dan akhir suatu kegiatan. Peristiwa diberi symbol lingkaran (nodes) dan nomor, dimana nomor dimulai dari nomor kecil bagi peristiwa yang mendahuluinya.

c) Waktu Kegiatan (activity time)

Activity time adalah kegiatan yang akan dilaksanakan dan berapa lama waktu penyelesaiannya. Ada 3 estimasi waktu yang digunakan dalam penyelesaian suatu kegiatan:

1. Waktu optimistik (a)

Waktu kegiatan yang dilaksanakan berjalan baik tidak ada hambatan.

2. Waktu realistik $(\mathrm{m})$

Waktu kegiatan yang dilaksanakan dalam kondisi normal dengan hambatan tertentu yang dapat diterima.

3. Waktu pesimistik (b)

Waktu kegiatan dilaksanakan terjadi hambatan lebih dari semestinya.

d) Taksiran Waktu Penyelesaian Kegiatan

Ketiga estimasi waktu kemudian digunakan untuk mendapatkan waktu kegiatan yang diharapkan (expected time) dengan rumus:

$$
t=\frac{a+4 m+b}{6}
$$

(Sumber :AryoAndriNugroho, 2007)

e) Penjadwalan proyek

Untuk menentukan jadwal proyek, harus dihitung dua waktu awal dan akhir untuk setiap kegiatan. Adapun dua waktu awal dan dua waktu akhir yaitu:

1. Earliest Start (ES) :early start atau mulai terdahulu adalah waktu paling awal dimana suatu kegiatan sudah dapat dimulai, dengan asumsi semua kegiatan pendahulu atau semua kegiatan yang mengawalinya sudah selesai dikerjakan.

2. Earliest Finish (EF) :early finish atau selesai terdahulu adalah waktu paling awal suatu kegiatan dapat selesai.

3. Latest Start (LS) :latest start atau mulai terakhir adalah waktu terakhir suatu kegiatan dapat dimulai sehingga tidak menunda waktu penyelesaian keseluruhan proyek. Latest start menunjukkan waktu toleransi terakhir dimana suatu kegiatan harus mulai dilakukan.

4. Latest Finish (LF) :Latest Finish atau selesai terakhir adalah waktu toleransi terakhir suatu kegiatan harus dapat selesai sehingga tidak menunda waktu penyelesaian kegiatan 
berikutnya dan keseluruhan proyek (Aryo Andri Nugroho, 2007).

Dalam menentukan jadwal proyek dapat menggunakan proses two-pass yang terdiri dari forward pass dan backward pass. ES dan EF ditentukanselama forward pass, sedangkan LS dan LF ditentukan selama backward pas.

Waktu kegiatan PERT dengan rumus

$$
t=\frac{a+4 m+b}{6}
$$

$$
\begin{aligned}
\text { ET } & =\frac{\mathbf{a}+\mathbf{4 m}+\mathbf{b}}{\mathbf{6}} \\
\text { a. ET } & =\frac{3+(4.4)+5}{6} \\
\text { b.ET } & =\frac{24}{6}=4 \\
& =\frac{2+(4.4)+4}{6}=3
\end{aligned}
$$

Cara untuk perhitungan selanjutnya yaitu menghitung ES (Early Start) dan EF (Early Finish) dengan rumus sebagai berikut (Budi Santoso,2009) :

\section{ESx = nilai terbesar dari $(\mathbf{E F p})$ \\ $\mathbf{E F x}=\mathbf{E S x}+\mathbf{E T x}$}

Notasi p menunjukkan aktivitas yang mendahului, sedangkan notasi $\mathrm{x}$ menunjukkan suatu kegiatan pada jaringan kerja.
1. Kegiatan
$\mathrm{ESa} \quad=0$
$\mathrm{EFa} \quad=0+4=4$
2. Kegiatan
$\mathrm{ESb}=4$
$\mathrm{EFb} \quad=3+3=7$

Untuk menghitung nilai LF dari kegiatan terakhir pada jaringan kerja sama dengan nilai EFnya. Pencarian LF (Late Start) dan LS (Late Finish) tersebut menggunakan rumus sebagai berikut :

\section{LFx = Nilai terminimdari LSp \\ LSx $=\mathbf{L F x}-\mathbf{E t x}$ sesudahnya.

$$
\begin{aligned}
& \text { 1. Kegiatan } \mathrm{LFa}=4 \\
& \text { 2. Kegiatan } \mathrm{LFb}=7 \\
& \mathrm{LSb} \quad=7-3=4
\end{aligned}
$$

Dimana notasi $\mathrm{x}$ menunjukkan suatu

\begin{tabular}{|c|c|c|c|c|c|c|c|}
\hline \multicolumn{2}{|r|}{ Altivitas } & Durasi & ES & EF & LS & LF & Slack \\
\hline $\mathbf{A}$ & Pelkejaan pendahuluan & 4 & 0 & 4 & 0 & 4 & 0 \\
\hline B & $\begin{array}{l}\text { Pelverjan tiang pancang } \\
\text { Pier head }\end{array}$ & 3 & 4 & 7 & 4 & 3 & 0 \\
\hline C & $\begin{array}{l}\text { Pekerjan Bektisting } \\
\text { stopper }\end{array}$ & 13 & 7 & 20 & 7 & 20 & 0 \\
\hline Dl & Pelkejsen cor beton & 5 & 20 & 25 & 20 & 25 & 0 \\
\hline D2 & $\begin{array}{l}\text { Pelkejaen perbersihan } \\
\text { stopper }\end{array}$ & 3 & 20 & 23 & 20 & 23 & 0 \\
\hline $\mathbf{E}$ & $\begin{array}{l}\text { Pekerjaan pasang list } \\
\text { pembersihan dan } \\
\text { instalasi }\end{array}$ & 5 & 23 & 28 & 23 & 28 & 0 \\
\hline $\mathbf{F}$ & $\begin{array}{l}\text { Pekerjaen } \\
\text { BekistingCollwwn }\end{array}$ & 3 & 28 & 31 & 26 & 31 & 0 \\
\hline G & Pelkerjan cor Colwmn & 4 & 31 & 35 & 31 & 35 & 0 \\
\hline H & $\begin{array}{l}\text { Pelkejaan finishing Pier } \\
\text { Cap dan Colwmn }\end{array}$ & 5 & 35 & 40 & 35 & 40 & 0 \\
\hline I & $\begin{array}{l}\text { Pelerjaen Bekisting pier } \\
\text { head }\end{array}$ & 3 & 40 & 43 & 40 & 43 & 0 \\
\hline $\mathrm{Jl}$ & Pelkerjaen cor beton & 3 & 43 & 46 & 43 & 46 & 0 \\
\hline $\mathrm{J} 2$ & $\begin{array}{l}\text { Pekerjaen pasang list } \\
\text { Anghur }\end{array}$ & 5 & 43 & 48 & 43 & 48 & 0 \\
\hline $\mathbf{K}$ & Pekejaan Biguall & 7 & 48 & 55 & 48 & 55 & 0 \\
\hline L & $\begin{array}{l}\text { Pelkejaen finishing } \\
\text { Pier head dan Bigwall }\end{array}$ & 6 & 55 & 61 & 55 & 61 & 0 \\
\hline
\end{tabular}
kegiatan dan notasi $\mathrm{p}$ menunjukkan kegiatan

Slack atau total Float (TF) yang merupakan waktu suatu kegiatan dapat ditunda tanpa mempengaruhi waktu penyelesaian proyek pada metode PERT dapat dihitung dengan rumus (Budi Santoso, 2009).

$$
\begin{array}{lll}
\text { TFx } & =\mathbf{L F x}- & \mathbf{D x}-\mathbf{E S x} \\
1 . & \mathrm{TFa} & =\mathrm{LFa}-\mathrm{Da}-\mathrm{ESa} \\
& & =4-4-0=0 \\
\text { 2. } & \mathrm{TFb} & =\mathrm{LFb}-\mathrm{Db}-\mathrm{ESb} \\
& & =7-3-4=0
\end{array}
$$

Tabel 8 Hasil Analisis Kegiatan Metode PERT

\section{Keterangan \\ ES - Early Start \\ EF - Early Finish \\ LS - Late Finish \\ LF - Late Start}

Dari alur kegiatan pada jaringan kerja pada metode PERT diperoleh lintasan kerja yang berwarna merah sebagai berikut:

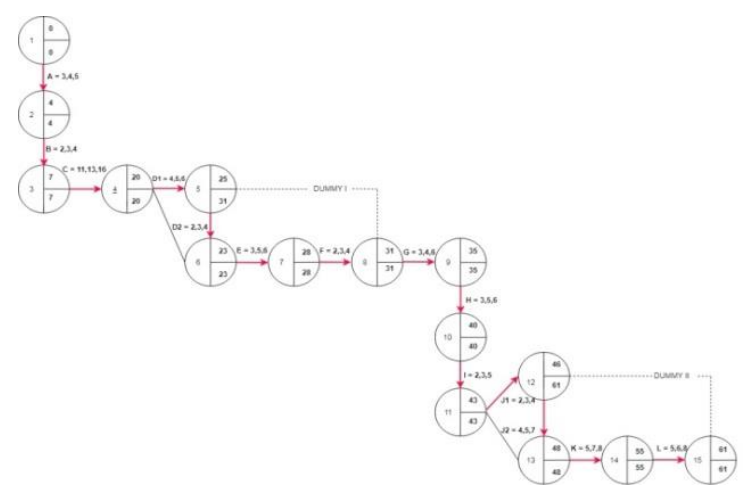

Gambar 4 Bentuk Diagram Network proyek

Kegiatan = A-B-C-D2-E-F-G-H-I-J2-K-L

$$
\begin{aligned}
& =4+3+13+3+5+3+4+5+3+5+7+ \\
& =61 \text { hari }
\end{aligned}
$$

Kegiatan = A-B-C-D1-E-F-G-H-I-J1-K-L

$$
\begin{aligned}
& =4+3+13+5+5+3+4+5+3+3+7+ \\
& =56 \text { hari }
\end{aligned}
$$

Kegiatan = A-B-C-D2-E-F-G-H-I-J1-K-L

$$
\begin{aligned}
& =4+3+13+3+5+3+4+5+3+3+7+ \\
& =60 \text { hari }
\end{aligned}
$$

Kegiatan = A-B-C-D1-E-F-G-H-I-J2-K-L

$$
\begin{aligned}
& =4+3+13+5+5+3+4+5+3+5+7+ \\
& =63 \text { hari }
\end{aligned}
$$


Maka yang menjadi jalur kritis adalah $\mathrm{A}-\mathrm{B}$ - C - D1 - E - F - G - H - I -J1 - K - L dengan lama durasi $=56$ hari.

\section{Kesimpulan Dan Saran}

\subsection{Kesimpulan}

Dari hasil pengolahan data dan analisis yang sudah dilakukan dapat ditarik kesimpulan sebagai berikut:

1. Berdasarkan metode Fuzzy Logic Application For Scheduling (FLASH) didapatkan selang perkiraan waktu penyelesaian proyek Pier Head jalan tol Krian Manyar Seksi II Bunder yaitu paling cepat 45 hari dan paling lama 79 hari dengan waktu paling mungkin 61 hari dengan nilai Defuzzyfikasi 62 hari.

2. Berdasarkan metode PERT didapatkan rata-rata waktu penyelesaian penyelesaian proyek Pier Head jalan tol Krian Manyar Seksi II Bunder dengan durasi 56 hari. Dimana hasil tersebut memperlihatkan perbedaan dengan waktu penyelesaian aktual sebesar 9 hari.

3. Dari hasil perhitungan menggunakan metode Fuzzy Logic Application For Scheduling (FLASH) Pada proyek Pier Head seksi II Bunder dengan didapatkan lintasan kritis dan kegiatan yang tidak boleh mengalami keterlambatan yaitu Pekerjaan pendahuluan Pekerjaan tiang pancang Pier head - Pekerjaan Bekisting stopper - Pekerjaan pembersihan stopper - Pekerjaan pasang list pembersihan dan instalasi - Pekerjaan Bekisting Column Pekerjaan cor Column - Pekerjaan finishing Pier Cap dan Column - Pekerjaan Bekisting pier head - Pekerjaan pasang list Angkur - Pekerjaan Bigwall - Pekerjaan finishing Pier head dan Bigwall,

4. Dengan metode PERT Pada proyek Pier Head jalan tol seksi II Bunder didapatkan lintasan kritis dan kegiatan yang tidak boleh mengalami keterlambatan Pekerjaan pendahuluan Pekerjaan tiang pancang Pier head - Pekerjaan Bekisting stopper - Pekerjaan cor betonPekerjaan pasang list pembersihan dan instalasi - Pekerjaan Bekisting Column - Pekerjaan cor Column - Pekerjaan finishing Pier Cap dan Column - Pekerjaan Bekisting pier head Pekerjaan cor beton - Pekerjaan Bigwall Pekerjaan finishing Pier head dan Bigwal. Perbandingan kedua lintasan kritis antara kedua metode sebagai untuk metode FLASH Pekerjaan pembersihan stopper, Pekerjaan pasang list Angkur (D2,J2) sedangkan untuk metode PERT melewati pekerjaan cor beton, pekerjaan cor beton (D1,J1)

\section{2 saran}

Berdasarkan hasil penelitian, maka beberapa saran berikut ini dapat dijadikan sebagai bahan pertimbangan:

1. Dalam lintasan jaringan kerja terdapat kegiatan kritis dan kegiatan hampir kritis, pada pelaksanaan proyek kegiatan kritis harus diperhatikan secara khusus karena akan berpengaruh terhadap umur proyek jika terjadi keterlambatan, tetapi untuk kegiatan hampir kritis juga harus diperhatikan karena ada kemungkinan kegiatan ini berubah menjadi kegiatan kritis karena memiliki float yang tidak besar.

2. Untuk penelitian berikutnya sebaiknya diperluas lagi dengan menggunakan metode penjadwalan proyek yang lain yang belum digunakan dalam penelitian ini.

\section{DAFTAR PUSTAKA}

Andrianto, Aries. 2015. “ Perencanaan jadwal proyek pembangunan dermaga VI di lokasi pelabuhan Gresik dengan metode PERT dan Fuzzy PERT”. GRESIK: SKRIPSI

Dipohusodo, Istimawan. 1995. Manajemen Proyek \& Konstruksi jilid 2. Penerbit Kanisius. Yogyakarta.

Hamzah, M H, El Unas. Saefoe dan Widiarsa. “ Penjadwalan Proyek Konstruksi dengan Metode Flash (Fuzzy Logic Application For Scheduling)". Malang.

Kerzne, H. 1984. "Project Management for the Small and Medium Sized Businesses". Hans Thamhain \& Van Nostrand Reinhold. Canada.

.Miftakhul, A H. 2014. Perencanaan Penjadwalan Proyek Kantor PT. Gresik Jasatama

Dengan Metode Fuzzy Logic Application For Scheduling (FLASH). Gresik: SKRIPSI.

Nugroho, Aryo A. 2007. “ Optimalisasi Penjadwalan Proyek Pada Pembangunan Gedung Khusus (LABORATORIUM) Stasiun Karantina Ikan Kelas 1 Tanjung Emas”. Semarang: SKRIPSI.

Nurhayati. 2010. “Manajemen Proyek”. Yogyakarta: Graha Ilmu.

Santoso, Budi. 2009." Manajemen Proyek". Surabaya: Graha Ilmu.

Siswanto, 2007. Operations Research. Erlangga, Jakarta

Soeharto, I (1997) “ Manajemen proyek dari konseptual sampai operasional”. Erlangga, jakarta.

Wibowo, A. 2001. “Alternatif Metode Penjadwalan Proyek Konstruksi Menggunakan Teori Set Samar”. Jakarta. 